\title{
Highly Dispersed Pt Species with Excellent Stability and Catalytic Performance by Reducing a Perovskite-Type Oxide Precursor for CO Oxidation
}

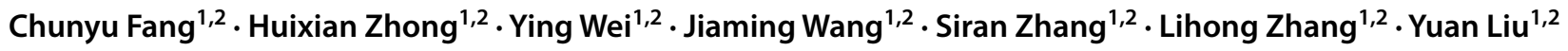

Received: 5 April 2018 / Revised: 20 May 2018 / Accepted: 22 May 2018 / Published online: 7 July 2018

(C) The Author(s) 2018

\begin{abstract}
A new scheme for the preparation of highly dispersed precious metal catalysts is proposed in this work. Samples of $\mathrm{LaCo}_{1-x} \mathrm{Pt}_{x} \mathrm{O}_{3} / \mathrm{SiO}_{2}(x=0.03,0.05,0.07,0.09$, and 0.10$)$ were prepared through a simple method of citrate acid complexation combined with impregnation. In a nanocrystallite of $\mathrm{LaCo}_{1-x} \mathrm{Pt}_{x} \mathrm{O}_{3}$, ions of lanthanum, cobalt, and platinum are evenly mixed at the atomic level and confined within the nanocrystallite. In the reduction process, platinum ions were reduced and migrated onto the surface of the nanocrystallite, and the platinum should be highly dispersed owing to the even mixing of the platinum ions in the precursor. When $x=0.05$ or lower, the highest dispersion of Pt could be achieved. The highly dispersed $\mathrm{Pt}$ is stable, because of the strong interaction between Pt atoms and the support. The catalysts were characterized by BET surface area, temperature-programmed reduction, X-ray diffraction, transmission electron microscopy, CO temperatureprogrammed desorption, and turnover frequency. Compared with general precious metal Pt catalysts, the $\mathrm{LaCo}_{0.95} \mathrm{Pt}_{0.05} \mathrm{O}_{3} /$ $\mathrm{SiO}_{2}$ catalyst exhibited better activity for $\mathrm{CO}$ oxidation, and it maintained stability at a high temperature of $400{ }^{\circ} \mathrm{C}$ for $250 \mathrm{~h}$ with complete $\mathrm{CO}$ conversion.
\end{abstract}

Keywords High dispersion $\cdot$ Perovskite-type oxide $\cdot$ Platinum $\cdot$ Carbon monoxide $\cdot$ Catalytic oxidation

\section{Introduction}

Supported precious metal catalysts are widely used in the industry for their very good catalytic performance. The size of metal nanoparticles (NPs) is a key element in terms of the catalytic activity. For general metal catalysts, only part of the metal atoms or ions serves as the active sites to play the catalytic role during the reaction. To improve the utilization of noble metals, higher distributions of the metal active sites are expected [1, 2]. Recently, theoretical and experimental results have proved that highly dispersed catalysts have better catalytic activity and selectivity than common metal particles [3]. Particularly for precious metal catalysts, the

Yuan Liu

yuanliu@tju.edu.cn

1 Tianjin Key Laboratory of Applied Catalysis Science and Engineering, School of Chemical Engineering and Technology, Tianjin University, Tianjin 300072, China

2 Collaborative Innovation Center of Chemical Science and Engineering (Tianjin), Tianjin 300072, China highly dispersed catalysts can improve the atom catalytic efficiency substantially, thus reducing the cost. At the same time, the highly dispersed metallic atoms make it possible to study the mechanism of heterogeneous catalysis at the molecular level [4, 5].

As mentioned above, highly dispersed catalysts have many advantages, but their preparation is a challenge. The key problem is the high surface free energy of atoms, which promotes aggregation to form small clusters [6]. The reported preparation methods for highly dispersed catalysts include the following: Ramos-Fernandez et al. [7] used the metal organic framework to prepare PTA-MOF catalysts for $\mathrm{CO}$ oxidation and the hydrogenation of toluene. Watanabe et al. [8] prepared highly dispersed $\mathrm{Pt}+\mathrm{Ru}$ alloy clusters through the co-deposition of platinum and ruthenium oxides at the atomic level for the electro-oxidation of methanol. In 2011, Qiao et al. [9] prepared a catalyst of single atom $\mathrm{Pt} / \mathrm{FeO}_{x}$ by a co-precipitation method for $\mathrm{CO}$ oxidation. A photochemical method was used to synthesize $\mathrm{Pd} / \mathrm{TiO}_{2}$ monatomic catalysts for styrene hydrogenation [10]. Hightemperature heat transfer atom trapping on polyhedral ceria and nanorods was adopted to synthesize thermally stable 
single-atom platinum-on-ceria catalysts for $\mathrm{CO}$ oxidation [11]. The methods above can only be applied to a narrow range, as they are expensive and of low-yield. Therefore, simple and feasible methods for the preparation are needed.

Perovskite-type oxides (PTOs) are mixed oxides with a cubic lattice structure of general formula $\mathrm{ABO}_{3}$, where rare earth elements are usually at the A-site positions and the smaller transition metals are located at the B-sites. The large range of tolerance factors $(0.75 \leq t \leq 1.0)$ makes it possible to tolerate significant partial substitution. At the same time, oxygen vacancies caused by doping of perovskites with different species are helpful to the activity of many oxidation reactions. PTOs also have other advantages, such as lower cost and higher thermal stability than noble metals. Furthermore, they exhibit excellent partial substitution tolerance for precious metals $(\mathrm{Pd}, \mathrm{Rh}$, and $\mathrm{Pt})$ and are capable of recycling the noble metal atoms in and out of the perovskite lattice in oxidizing and reducing conditions, which can prevent the aggregation of the metal atoms [12-14]. The specific surface area of a PTO is low, generally below $10 \mathrm{~m}^{2} / \mathrm{g}$ [15]. Loading a PTO on a support with high specific surface area is one strategy to overcome this problem.

In this article, a new scheme for preparing highly dispersed catalyst was proposed, as shown in Scheme 1. Taking advantage of the strong interaction between a PTO and precious metals (Pt, here), by supporting a PTO with high specific surface area on silica, it is possible to overcome their disadvantage of low specific surface area. A PTO of $\mathrm{LaCo}_{0.95} \mathrm{Pt}_{0.05} \mathrm{O}_{3}$ was highly dispersed on $\mathrm{SiO}_{2}$, where the

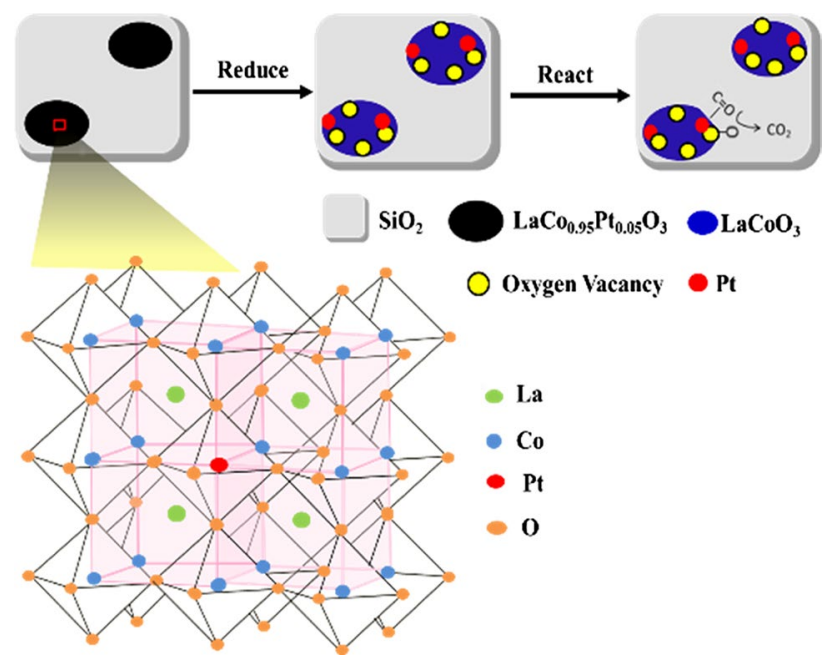

Scheme 1 A schematic illustration for preparing the highly dispersed catalyst of $\mathrm{Pt} / \mathrm{LaCoO}_{3} / \mathrm{SiO}_{2}$

ions of Pt should be uniformly dispersed in the PTO lattice. In the reduction process, ions of Pt should be reduced and migrate onto the surface of the PTO to achieve high dispersions. The as-prepared catalyst showed high activity and very good stability to $\mathrm{CO}$ oxidation.

\section{Experimental}

\section{Catalyst Preparation}

\section{Materials}

The catalysts were prepared by a citric acid complexation, combined with an incipient wetness impregnation method. The chemicals involved in the preparation of the catalysts were as follows: $\mathrm{La}\left(\mathrm{NO}_{3}\right)_{3} \cdot 6 \mathrm{H}_{2} \mathrm{O}, \mathrm{Co}\left(\mathrm{NO}_{3}\right)_{3} \cdot 6 \mathrm{H}_{2} \mathrm{O}$, and citric acid $\left(\mathrm{C}_{6} \mathrm{H}_{8} \mathrm{O}_{7}\right)$ supplied by Aladdin Industrial Corporation, China; $\mathrm{H}_{2} \mathrm{PtCl}_{6} \cdot 6 \mathrm{H}_{2} \mathrm{O}$ procured from Tianjin Delan Fine Chemical Plant; $\mathrm{C}_{2} \mathrm{H}_{6} \mathrm{O}_{2}$ purchased from Tianjin Guangfu Fine Chemical Research Institute; and silica $\left(\mathrm{SiO}_{2}\right)$ commercially available from Qingdao Bangkai Separation Material Co., Ltd.

\section{Preparation of $\mathrm{LaCo}_{1-x} \mathrm{Pt}_{x} \mathrm{O}_{3} / \mathrm{SiO}_{2}$}

$\mathrm{LaCo}_{0.95} \mathrm{Pt}_{0.05} \mathrm{O}_{3} / \mathrm{SiO}_{2}$ is given as the example to illustrate the preparation of $\mathrm{LaCo}_{1-x} \mathrm{Pt}_{x} \mathrm{O}_{3} / \mathrm{SiO}_{2}$. Typically, $2 \mathrm{~g}$ of $\mathrm{LaCo}_{0.95} \mathrm{Pt}_{0.05} \mathrm{O}_{3} / \mathrm{SiO}_{2}$ was prepared according to the following method. The support, $1.74 \mathrm{~g}$ of $\mathrm{SiO}_{2}$, was calcined at $700{ }^{\circ} \mathrm{C}$ for $6 \mathrm{~h}$ to break down impurities and then dried at $120{ }^{\circ} \mathrm{C}$ for $12 \mathrm{~h}$ to remove absorbed air and water. The $\mathrm{SiO}_{2}$ support was incipient-wetness-impregnated with an aqueous solution of lanthanum nitrate $(1.03 \mathrm{mmol})$, cobalt nitrate $(0.98 \mathrm{mmol})$, and chloroplatinic acid $(0.05 \mathrm{mmol})$ at a $\mathrm{La} / \mathrm{Co} / \mathrm{Pt}$ molar ratio of 1:0.95:0.05, while citric acid in $120 \mathrm{~mol} \%$ of the total cations $(2.47 \mathrm{mmol})$ and ethylene glycol in $20 \mathrm{~mol} \%$ of the citric acid $(0.49 \mathrm{mmol})$ were added. The mixture was left for $24 \mathrm{~h}$ to disperse evenly. After complexing for $6 \mathrm{~h}$ at $80{ }^{\circ} \mathrm{C}$, the sample was dried for $12 \mathrm{~h}$ at $120^{\circ} \mathrm{C}$. Then, the sample was calcined at $350{ }^{\circ} \mathrm{C}$ for $2 \mathrm{~h}$ with a heating rate of $2{ }^{\circ} \mathrm{C} / \mathrm{min}$ to decompose citric acid and subsequently was washed to remove chloride with deionized water. After drying at $120{ }^{\circ} \mathrm{C}$ for $12 \mathrm{~h}$, the sample was calcined at $700{ }^{\circ} \mathrm{C}$ for $6 \mathrm{~h}$ with a heating rate of $2{ }^{\circ} \mathrm{C} / \mathrm{min}$. The mass fractions of $\mathrm{Pt}$ in the calcined catalysts of $\mathrm{LaCo}_{0.97} \mathrm{Pt}_{0.03} \mathrm{O}_{3} / \mathrm{SiO}_{2}, \mathrm{LaCo}_{0.95} \mathrm{Pt}_{0.05} \mathrm{O}_{3} /$ $\mathrm{SiO}_{2}, \mathrm{LaCo}_{0.93} \mathrm{Pt}_{0.07} \mathrm{O}_{3} / \mathrm{SiO}_{2}, \mathrm{LaCo}_{0.91} \mathrm{Pt}_{0.09} \mathrm{O}_{3} / \mathrm{SiO}_{2}$, and $\mathrm{LaCo}_{0.90} \mathrm{Pt}_{0.10} \mathrm{O}_{3} / \mathrm{SiO}_{2}$ are $0.3,0.5,0.7,0.88$, and $1 \%$, respectively, and the mass fraction of $\mathrm{LaCo}_{1-x} \mathrm{Pt}_{x} \mathrm{O}_{3}$ in all of the catalysts is $13 \%$.

Similarly, $\mathrm{Pt} / \mathrm{SiO}_{2}$ and $\mathrm{LaCoPtO}_{x} / \mathrm{SiO}_{2}$ were prepared by the same method with a mass fraction of $0.5 \%$ for $\mathrm{Pt}$, except that no citric acid or ethylene glycol was added during the preparation process. $\mathrm{LaCoO}_{3} / \mathrm{SiO}_{2}$ was also prepared by the same method with a mass fraction of $13 \%$ for the perovskite. 
For comparison, unsupported PTOs of $\mathrm{LaCo}_{1-x} \mathrm{Pt}_{x} \mathrm{O}_{3}$ were prepared similarly as for $\mathrm{LaCo}_{1-x} \mathrm{Pt}_{x} \mathrm{O}_{3} / \mathrm{SiO}_{2}$, except that no $\mathrm{SiO}_{2}$ support was added for impregnation.

\section{Catalyst Characterization}

Specific surface areas and hole structures were calculated by the BET method and the BJH model. The data came from a Micromeritics apparatus, model ASAP-2020, and were collected at $-196{ }^{\circ} \mathrm{C}$. Before the measurements, $200 \mathrm{mg}$ of samples were pretreated for $2 \mathrm{~h}$ at $300{ }^{\circ} \mathrm{C}$ to remove absorbed air and moisture.

$\mathrm{H}_{2}$-temperature-programmed reduction $\left(\mathrm{H}_{2}\right.$-TPR) experiments were performed on a Thermo-Finnigan TP-5079 which was equipped with a thermal conductivity detector. Samples of $150 \mathrm{mg}$ were heated from 30 to $900{ }^{\circ} \mathrm{C}$ at a heating rate of $10^{\circ} \mathrm{C} / \mathrm{min}$ under a reduction gas mixture of $5 \mathrm{vol} \% \mathrm{H}_{2} /$ Ar with a flow rate of $25 \mathrm{~cm}^{3} / \mathrm{min}$. It should be noted that $19.5 \mathrm{mg}$ of $\mathrm{LaCoO}_{3}$ and $130.5 \mathrm{mg}$ of quartz sand were mixed for the TPR tests.

$\mathrm{X}$-ray diffraction (XRD) experiments were conducted on a Bruker D8-Focus X-ray diffractometer with nickel-filtered $\mathrm{Cu} \mathrm{K} \alpha$ radiation $(\lambda=1.5406 \AA$ ). The data range was from 15 to $85^{\circ}$ ( $2 \theta$ range), with a scanning speed of $8 \% \mathrm{~min}$.

Transmission electron microscopy (TEM) measurements were performed on a Technai $\mathrm{G}^{2} \mathrm{~F} 20$ transmission electron microscope. The Pt-containing samples were pretreated at $220^{\circ} \mathrm{C}$ in hydrogen for $2 \mathrm{~h}$, followed by grinding and dispersing in ethanol. The samples were loaded onto $\mathrm{Cu}$ grid for testing.

During $\mathrm{CO}$ temperature-programmed desorption (COTPD) measurements, the $\mathrm{LaCo}_{1-x} \mathrm{Pt}_{x} \mathrm{O}_{3} / \mathrm{SiO}_{2}$ catalysts were first reduced in $\mathrm{H}_{2}$ at $220{ }^{\circ} \mathrm{C}$ for $2 \mathrm{~h}$. The chemisorption of $\mathrm{CO}$ onto the catalysts was performed in a reactor at atmospheric pressure and $25^{\circ} \mathrm{C}$. The catalyst was outgassed and purged with helium of ultrahigh purity grade $(99.9999 \%$, $30 \mathrm{~cm}^{3} / \mathrm{min}$ ) at $400{ }^{\circ} \mathrm{C}$ for $0.5 \mathrm{~h}$. The sample was purged at $50{ }^{\circ} \mathrm{C}$ for $3 \mathrm{~h}$ and allowed to adsorb $\mathrm{CO}$ under $\mathrm{CO}$ atmosphere for $2 \mathrm{~h}$. Then, TPD measurements were completed at a constant heating rate $\left(5{ }^{\circ} \mathrm{C} / \mathrm{min}\right)$ from 50 to $500{ }^{\circ} \mathrm{C}$ under helium flow $\left(30 \mathrm{~cm}^{3} / \mathrm{min}\right)$ by an SRS RGA300 quadrupole mass spectrometer. The Pt dispersion $(D)$ was calculated based on the following equation [16]:

$D(\%)=\frac{M_{\mathrm{CO}} \times \mathrm{SF} \times \mathrm{FW}_{\mathrm{m}}}{\mathrm{WF}_{\mathrm{m}} \times m_{\text {cat }}} \times 100$

where $M_{\mathrm{CO}}$ is the amount of $\mathrm{CO}$ adsorption in $\mu \mathrm{mol}$; $\mathrm{SF}$ is the stoichiometric factor, i.e., the $\mathrm{Pt} / \mathrm{CO}$ ratio in chemisorption, which is 1 in this study [17]; $\mathrm{FW}_{\mathrm{m}}$ is the formula weight of the metal Pt; $\mathrm{WF}_{\mathrm{m}}$ is the weight fraction of the metal Pt in the catalyst; and $m_{\text {cat }}$ is the mass of the catalyst.
Based on the Pt dispersion in the catalyst, the turnover frequency (TOF) value at $145{ }^{\circ} \mathrm{C}$ was calculated according to the following equation [18]:

$\operatorname{TOF}\left(\mathrm{s}^{-1}\right)=X_{\mathrm{CO}} F_{\mathrm{CO}} \frac{M_{\mathrm{Pt}}}{m_{\mathrm{cat}} X_{\mathrm{Pt}} D_{\mathrm{Pt}}}$

where $X_{\mathrm{CO}}$ is the $\mathrm{CO}$ conversion at $145^{\circ} \mathrm{C} ; F_{\mathrm{CO}}$ is the flow rate of $\mathrm{CO}$ in mol/s; $m_{\text {cat }}$ is the mass of catalyst; $X_{\mathrm{Pt}}$ is the $\mathrm{Pt}$ loading in the catalyst; $D_{\mathrm{Pt}}$ is the dispersion of $\mathrm{Pt}$ which was calculated based on the CO-TPD results; and $M_{\mathrm{Pt}}$ is the molar weight of $\mathrm{Pt}(195.1 \mathrm{~g} / \mathrm{mol})$.

\section{Catalytic Performance Test for CO Oxidation}

The catalytic activity measurements were performed on a fixed bed micro-reactor at atmospheric pressure. Firstly, a $100 \mathrm{mg}$ sample was reduced at $220^{\circ} \mathrm{C}$ for $2 \mathrm{~h}$ in $\mathrm{H}_{2}$ atmosphere with a heating rate of $5{ }^{\circ} \mathrm{C} / \mathrm{min}$. The feed gases contained $1 \% \mathrm{CO}, 1 \% \mathrm{O}_{2}$, and $98 \mathrm{vol} \% \mathrm{~N}_{2}$ and reached the flow rate of $40 \mathrm{~mL} / \mathrm{min}$ in total. The catalyst sample was well distributed from 40 to 60 mesh. A thermocouple was inserted into the catalyst bed and used to measure the reaction temperature. The reaction exhaust was analyzed by an online gas chromatograph, SP-3420, which was equipped with a TCD and a 5 A molecular sieve column. The performance of samples was determined by $\mathrm{CO}$ conversion, which was defined as follows [19]:

Conversion of $\mathrm{CO}(\%): X_{\mathrm{CO}}=\frac{[\mathrm{CO}]_{\text {in }}-[\mathrm{CO}]_{\text {out }}}{[\mathrm{CO}]_{\text {in }}} \times 100$

where $[\mathrm{CO}]_{\text {in }}$ is the concentration of $\mathrm{CO}$ in the feed gases and $[\mathrm{CO}]_{\text {out }}$ is the concentration of $\mathrm{CO}$ in the effluent stream.

\section{Results and Discussion}

\section{Catalyst Characterizations}

\section{$\mathrm{N}_{2}$ Adsorption and Desorption Isotherms}

Nitrogen adsorption-desorption isotherms and the $\mathrm{BJH}$ pore size distribution of $\mathrm{SiO}_{2}$ and $\mathrm{LaCo}_{0.95} \mathrm{Pt}_{0.05} \mathrm{O}_{3} / \mathrm{SiO}_{2}$ are shown in Fig. 1. The isotherms belong to Type IV under IUPAC classifications [20], which closely relates to the properties of a mesoporous structure. As shown in Fig. 1, the most probable size and the specific surface area declined slightly from $9.45 \mathrm{~nm}$ and $369.8 \mathrm{~m}^{2} / \mathrm{g}$ for the $\mathrm{SiO}_{2}$ support to $8.76 \mathrm{~nm}$ and $326.6 \mathrm{~m}^{2} / \mathrm{g}$ for $\mathrm{LaCo}_{0.95} \mathrm{Pt}_{0.05} \mathrm{O}_{3} / \mathrm{SiO}_{2}$, respectively, which is likely caused by the blockage of some mesopores by the NPs of the PTO. The average pore size $(12 \mathrm{~nm}$ ) is larger than the size of the PTO (below $9 \mathrm{~nm}$ ), 
which can be seen in Fig. 4a-c, meaning that the NPs of the PTO can enter the mesopores. The specific surface area of the $\mathrm{SiO}_{2}$ support is large enough to highly disperse the PTO of $\mathrm{LaCo}_{0.95} \mathrm{Pt}_{0.05} \mathrm{O}_{3}$ when the amount of the PTO loaded is $13 \mathrm{wt} \%$.

\section{Temperature-Programmed Reduction (TPR)}

The TPR profiles are shown in Fig. 2. The reduction curves of $\mathrm{LaCoO}_{3}$ have been well studied, where the peak at the low temperature of approximately $400{ }^{\circ} \mathrm{C}$ is attributed to the reduction of $\mathrm{Co}^{3+}$ to $\mathrm{Co}^{2+}$, and the peak at high temperature of approximately $570{ }^{\circ} \mathrm{C}$ is attributed to the reduction of $\mathrm{Co}^{2+}$ to metallic $\mathrm{Co}^{0}[21,22]$. Compared with $\mathrm{LaCoO}_{3}$, for $\mathrm{LaCoO}_{3} / \mathrm{SiO}_{2}$, the peak at around $570{ }^{\circ} \mathrm{C}$ moved toward a higher temperature, which is due to the effect of the carrier. Compared with $\mathrm{LaCoO}_{3} / \mathrm{SiO}_{2}$, the TPR peaks for $\mathrm{LaCo}_{1-x} \mathrm{Pt}_{x} \mathrm{O}_{3} / \mathrm{SiO}_{2}$ shifted back to lower temperatures, and the magnitude of the shift increased with the increase in $\mathrm{Pt}$ content in the catalyst, which agrees with the shift due to the hydrogen spillover from the sites of $\mathrm{Pt}$ as pointed out in previous works $[23,24]$. The most important information is that the outlines of the TPR profiles of $\mathrm{LaCo}_{1-x} \mathrm{Pt}_{x} \mathrm{O}_{3} / \mathrm{SiO}_{2}$ are similar to that of the PTO of $\mathrm{LaCoO}_{3}$, indicating that PTO was formed as $\mathrm{LaCo}_{1-x} \mathrm{Pt}_{x} \mathrm{O}_{3} / \mathrm{SiO}_{2}$.

Ions of $\mathrm{Pt}$ in the PTO lattice of $\mathrm{LaCo}_{1-x} \mathrm{Pt}_{x} \mathrm{O}_{3} / \mathrm{SiO}_{2}$ can easily be reduced at a reduction temperature generally lower than $300{ }^{\circ} \mathrm{C}[3,17,19]$. Additionally, the content of $\mathrm{Pt}$ in $\mathrm{LaCo}_{1-x} \mathrm{Pt}_{x} \mathrm{O}_{3} / \mathrm{SiO}_{2}$ is small; therefore, no reduction peaks corresponding to the ions of $\mathrm{Pt}$ were detected. The TPR results indicate that after reduction, $\mathrm{LaCo}_{1-x} \mathrm{Pt}_{x} \mathrm{O}_{3} / \mathrm{SiO}_{2}$ was converted to $\mathrm{Pt} / \mathrm{LaCoO} / \mathrm{SiO}_{2}$, which is further confirmed by the following XRD and TEM results.

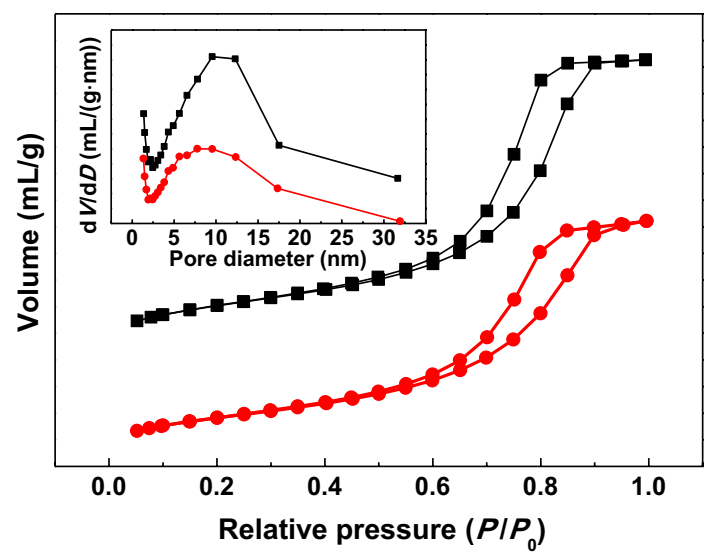

Fig. 1 Nitrogen adsorption-desorption isotherms and $\mathrm{BJH}$ pore diameter distributions, (square) $\mathrm{SiO}_{2}$ calcined at $700{ }^{\circ} \mathrm{C}$, (circle) $\mathrm{LaCo}_{0.95} \mathrm{Pt}_{0.05} \mathrm{O}_{3} / \mathrm{SiO}_{2}$ calcined at $700{ }^{\circ} \mathrm{C}$

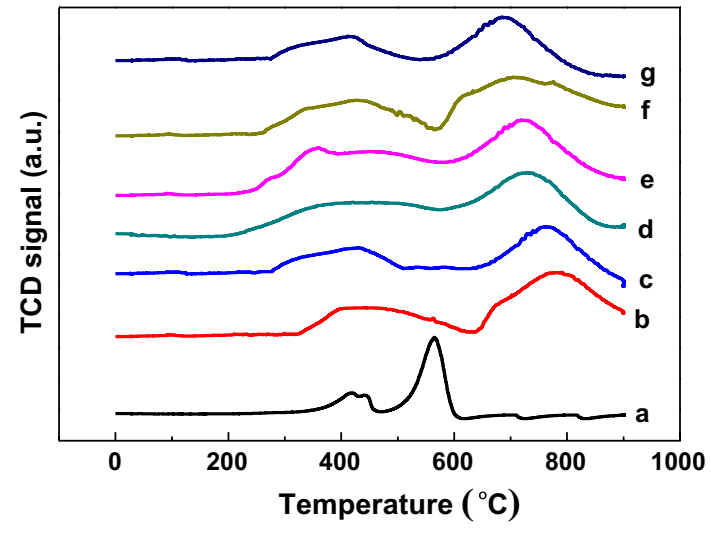

Fig. 2 TPR profiles of $\mathrm{LaCoO}_{3}, \mathrm{~b} \mathrm{LaCoO} / \mathrm{SiO}_{2}, \mathrm{c} \mathrm{LaCo}_{0.97} \mathrm{Pt}_{0.03} \mathrm{O}_{3} /$ $\mathrm{SiO}_{2}, \quad$ d $\quad \mathrm{LaCo}_{0.95} \mathrm{Pt}_{0.05} \mathrm{O}_{3} / \mathrm{SiO}_{2}, \quad$ e $\quad \mathrm{LaCo}_{0.93} \mathrm{Pt}_{0.07} \mathrm{O}_{3} / \mathrm{SiO}_{2}, \quad$ f $\mathrm{LaCo}_{0.91} \mathrm{Pt}_{0.09} \mathrm{O}_{3} / \mathrm{SiO}_{2}, \mathrm{~g} \mathrm{LaCo}_{0.90} \mathrm{Pt}_{0.10} \mathrm{O}_{3} / \mathrm{SiO}_{2}$

\section{XRD Results}

Figure 3A shows XRD patterns of the unsupported PTOs of $\mathrm{LaCo}_{1-x} \mathrm{Pt}_{x} \mathrm{O}_{3}$. The characteristic diffraction peaks of the perovskite phase at $2 \theta=32.9,33.3,47.5$, and $59.0^{\circ}$ are clearly seen, and no peaks corresponding to other impurity phases could be observed, suggesting that the PTOs were synthesized well. From the enlarged pattern of $\mathrm{LaCo}_{1-x} \mathrm{Pt}_{x} \mathrm{O}_{3}$ in Fig. 3B, it is seen that the diffraction peaks of the perovskite phase shifted to smaller values of $2 \theta$, which means that the crystal lattice spacing of the perovskite phase increased. The shift increased with the increase in the Pt content in the PTOs. This should be indicative of the imbedding of Pt ions into the lattice of PTO. The size of the Pt ion is larger than the size of the Co ion, leading to the increase in the lattice spacing. Since no diffraction peak corresponding to platinum or platinum oxide was detected, entering of Pt ions into the lattice of PTO is supported.

The XRD patterns of the supported catalysts of $\mathrm{LaCo}_{0.95} \mathrm{Pt}_{0.05} \mathrm{O}_{3} / \mathrm{SiO}_{2}$ and $\mathrm{SiO}_{2}$ are shown in Fig. $3 \mathrm{C}$. Besides the broad diffraction peaks corresponding to $\mathrm{SiO}_{2}$, weak diffraction peaks corresponding to the perovskite phase could be detected, indicating that the PTOs were successfully supported on silica. The peak intensity of PTO increased with the increase in PTO loading amount, and when the loading amount of PTOs is $13 \mathrm{wt} \%$, diffraction peaks of perovskite could hardly be detected, suggesting that the PTOs were highly dispersed, which is consistent with the TEM results in Fig. 4.

\section{TEM Images}

Figure $4 \mathrm{a}, \mathrm{b}$ shows representative TEM images of the calcined $\mathrm{LaCo}_{0.95} \mathrm{Pt}_{0.05} \mathrm{O}_{3} / \mathrm{SiO}_{2}$. From the images of $\mathrm{LaCo}_{0.95} \mathrm{Pt}_{0.05} \mathrm{O}_{3} / \mathrm{SiO}_{2}$, many of PTO NPs with sizes below 

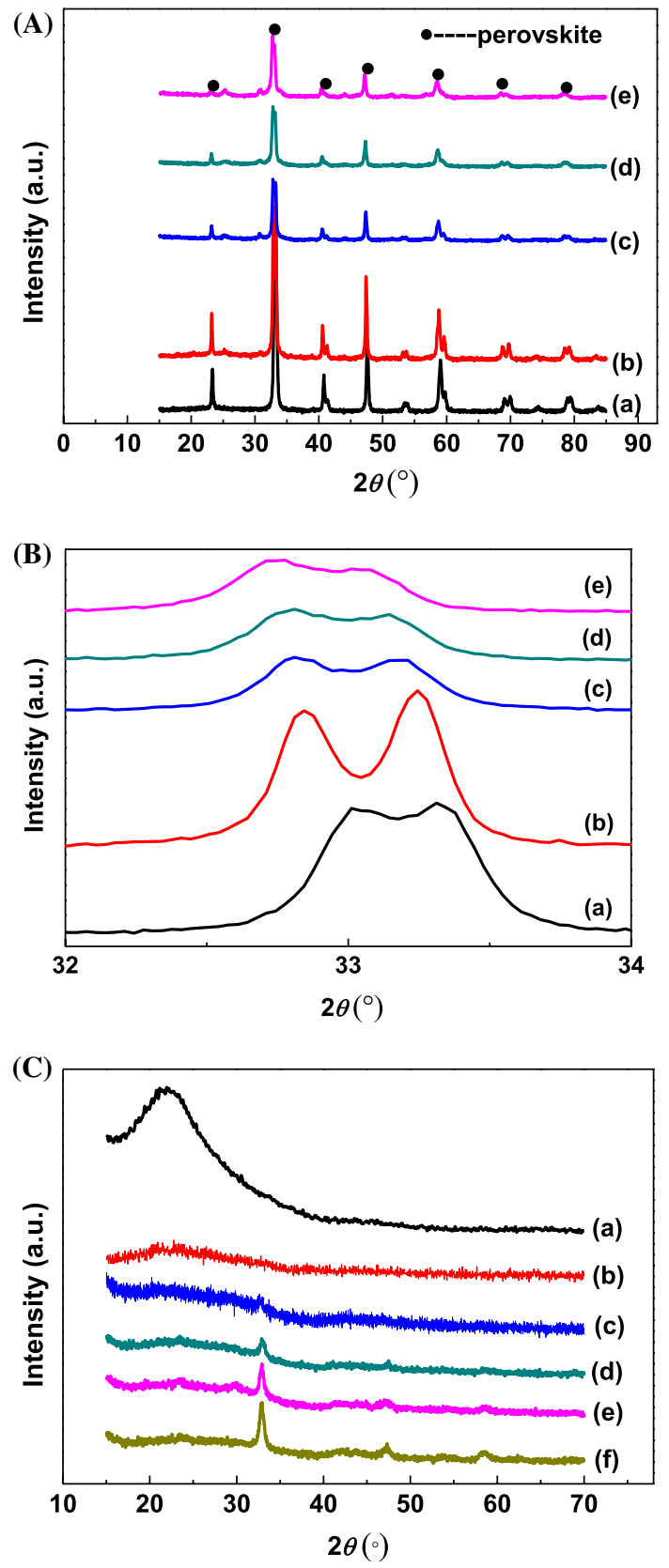

Fig. 3 XRD patterns of $\mathbf{A}: \quad$ a $\mathrm{LaCoO}_{3}, \quad$ b $\mathrm{LaCo}_{0.95} \mathrm{Pt}_{0.05} \mathrm{O}_{3}$, c $\mathrm{LaCo}_{0.93} \mathrm{Pt}_{0.07} \mathrm{O}_{3}, \mathrm{~d} \mathrm{LaCo}_{0.91} \mathrm{Pt}_{0.09} \mathrm{O}_{3}$, and $\mathrm{e} \mathrm{LaCo}_{0.89} \mathrm{Pt}_{0.11} \mathrm{O}_{3} ; \mathbf{B}$ : the partially enlarged drawing of $\mathbf{A}$; $\mathbf{C}$ : a $\mathrm{SiO}_{2}$, b $13 \% \mathrm{LaCo}_{0.95} \mathrm{Pt}_{0.05} \mathrm{O}_{3} /$ $\mathrm{SiO}_{2}$, c $25 \% \mathrm{LaCo}_{0.95} \mathrm{Pt}_{0.05} \mathrm{O}_{3} / \mathrm{SiO}_{2}$, d $30 \% \mathrm{LaCo}_{0.95} \mathrm{Pt}_{0.05} \mathrm{O}_{3} / \mathrm{SiO}_{2}$, e $40 \% \mathrm{LaCo}_{0.95} \mathrm{Pt}_{0.05} \mathrm{O}_{3} / \mathrm{SiO}_{2}$, f $50 \% \mathrm{LaCo}_{0.95} \mathrm{Pt}_{0.05} \mathrm{O}_{3} / \mathrm{SiO}_{2}$

$9 \mathrm{~nm}$ can be found on the surface of $\mathrm{SiO}_{2}$. Figure $4 \mathrm{~b}$ shows a representative crystallite of the PTO, with a crystal spacing of $2.74 \AA$, corresponding to the crystalline plane [110] of $\mathrm{LaCo}_{0.95} \mathrm{Pt}_{0.05} \mathrm{O}_{3}$.

After reduction at $220{ }^{\circ} \mathrm{C}$, the NPs with an interplanar crystal spacing of $2.72 \AA$, consistent with crystal spacing of plane [110] for $\mathrm{LaCoO}_{3}$, can be found in Fig. 4d. The slight
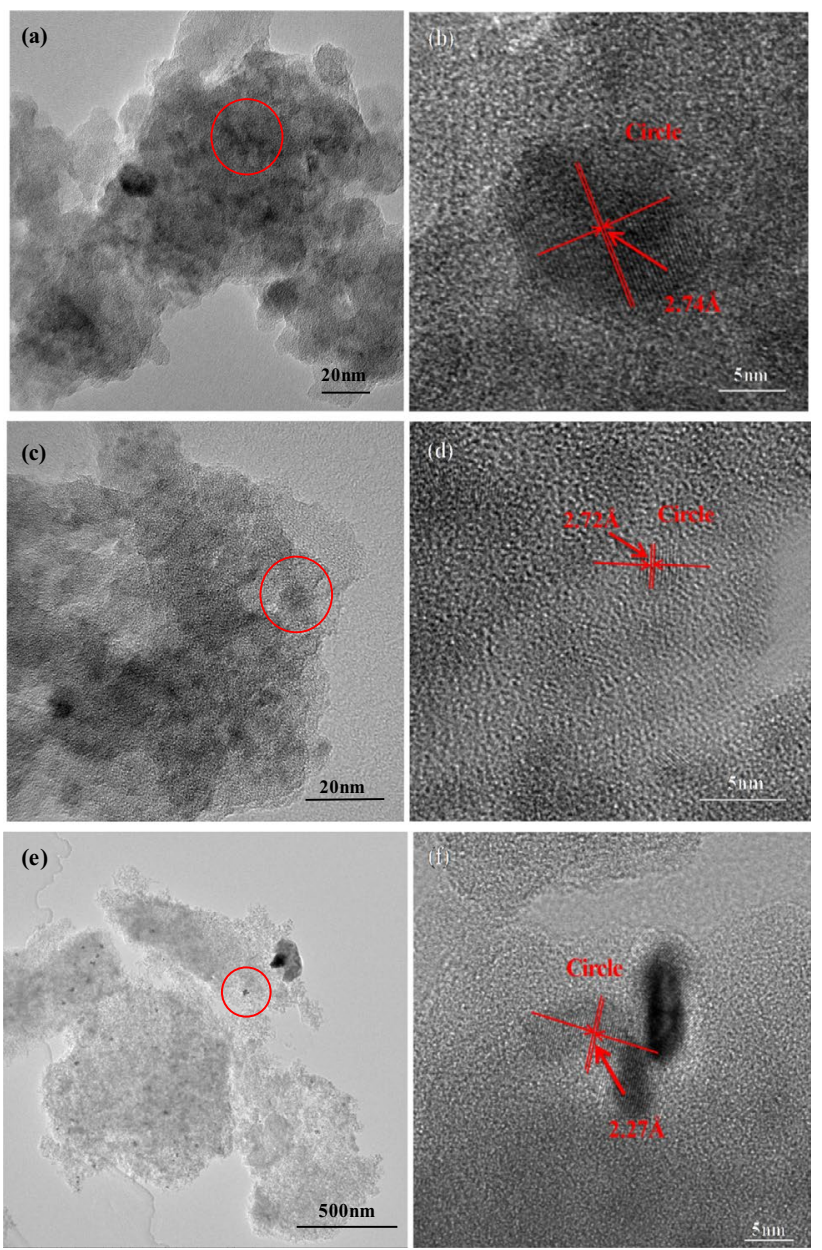

Fig. 4 TEM images of a fresh $\mathrm{LaCo}_{0.95} \mathrm{Pt}_{0.05} \mathrm{O}_{3} / \mathrm{SiO}_{2}$; $\mathbf{b}$ the enlarged view of $\mathbf{a}$ in the red circle; $\mathbf{c} \mathrm{LaCo}_{0.95} \mathrm{Pt}_{0.05} \mathrm{O}_{3} / \mathrm{SiO}_{2}$ reduced at $220{ }^{\circ} \mathrm{C}$; d the enlarged view of $\mathbf{c}$ in the red circle; $\mathbf{e} \mathrm{LaCo}_{0.90} \mathrm{Pt}_{0.10} \mathrm{O}_{3} / \mathrm{SiO}_{2}$ reduced at $220{ }^{\circ} \mathrm{C}$; $\mathbf{f}$ the enlarged view of $\mathbf{e}$ in the red circle

decrease in the lattice spacing from $2.74 \AA$ in Fig. 4 b to 2.72 $\AA$ here would be attributed to platinum ions' escaping from the perovskite lattice. At the same time, no platinum lattices can be detected for $\mathrm{LaCo}_{0.95} \mathrm{Pt}_{0.05} \mathrm{O}_{3} / \mathrm{SiO}_{2}$, indicating that platinum is highly dispersed on the support. It agrees well with XRD results and our assumption in Scheme 1.

The representative images of $\mathrm{LaCo}_{0.90} \mathrm{Pt}_{0.10} \mathrm{O}_{3} / \mathrm{SiO}_{2}(\mathrm{Pt}$ loading is $1 \mathrm{wt} \%$ ) reduced at $220^{\circ} \mathrm{C}$ are shown in Fig. 4e, f; the crystallites of $\mathrm{LaCoO}_{3}$ can be seen. The image in Fig. $4 \mathrm{f}$ shows a typical metallic Pt NP. The crystal lattice spacing is $2.27 \AA$, which is in accordance with the crystalline plane [111] of platinum metal. The result indicates that too much $\mathrm{Pt}$ added resulted in the comparatively poor dispersion of Pt atoms. 

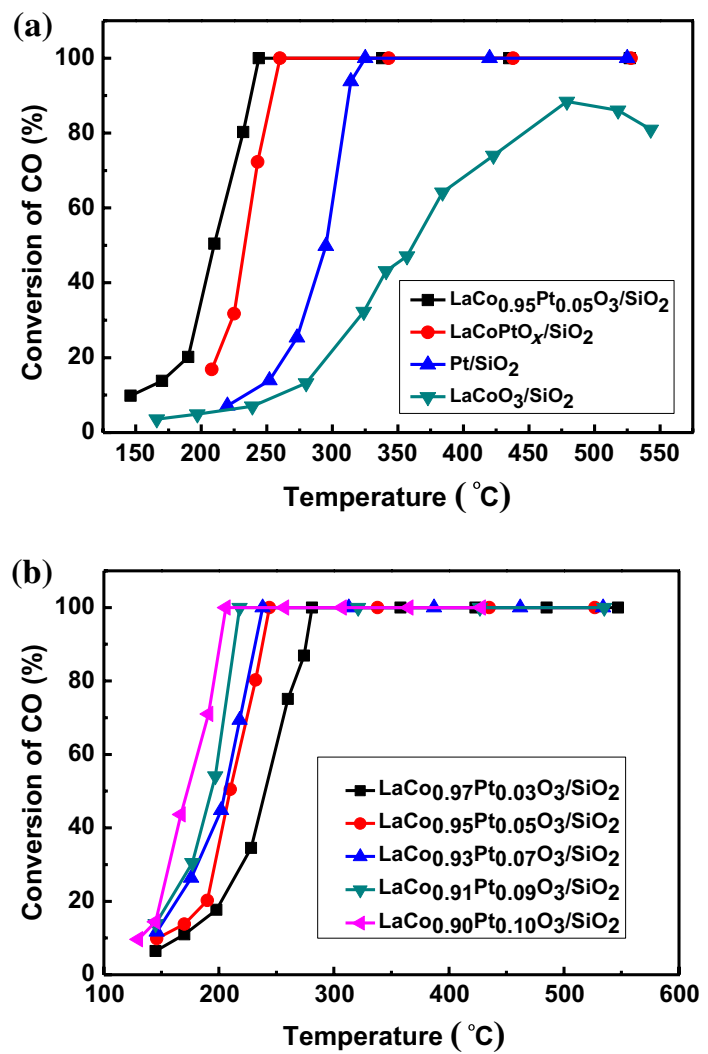

Fig. 5 Variation of $\mathrm{CO}$ conversion with reaction temperature for a supported catalysts with the same platinum content of $0.5 \mathrm{wt} \%$ or the same PTO content of $13 \mathrm{wt} \%$, b the catalysts of PTO supported on $\mathrm{SiO}_{2}$ with different platinum contents of $0.3,0.5,0.7,0.88 \%$, and 1 wt $\%$. Reaction conditions: $1 \% \mathrm{CO}, 1 \% \mathrm{O}_{2}, 98 \mathrm{vol} \% \mathrm{~N}_{2}$ balance, space velocity $=24,000 \mathrm{~mL} /\left(\mathrm{g}_{\text {cat }} \mathrm{h}\right)$

\section{Catalytic Performance}

To study the catalytic performance of the supported $\mathrm{Pt}$ catalysts, $\mathrm{CO}$ oxidation was chosen as the probe reaction, which is an extensively used probe and a very important reaction in environmental protection [25]. CO conversions over the catalysts with the same platinum content of $0.5 \mathrm{wt} \%$ are shown in Fig. 5a. The complete $\mathrm{CO}$ oxidation temperatures are 240,260 , and $320{ }^{\circ} \mathrm{C}$ for $\mathrm{LaCo}_{0.95} \mathrm{Pt}_{0.05} \mathrm{O}_{3} / \mathrm{SiO}_{2}$, $\mathrm{LaCoPtO}_{x} / \mathrm{SiO}_{2}$, and $\mathrm{Pt} / \mathrm{SiO}_{2}$, respectively. Meanwhile, the highest $\mathrm{CO}$ conversion is about $90 \%$ for $\mathrm{LaCoO}_{3} / \mathrm{SiO}_{2}$ at a temperature of $480{ }^{\circ} \mathrm{C}$. It indicates that the catalyst prepared according to Scheme 1 is highly active.

Considering the similar synthesis process and perovskite content between $\mathrm{LaCo}_{0.95} \mathrm{Pt}_{0.05} \mathrm{O}_{3} / \mathrm{SiO}_{2}$ and $\mathrm{LaCoO}_{3} /$ $\mathrm{SiO}_{2}$, the huge difference in activity comes from the small amount of metallic platinum. Reducing $\mathrm{LaCo}_{1-x} \mathrm{Pt}_{x} \mathrm{O}_{3} / \mathrm{SiO}_{2}$ resulted in $\mathrm{Pt} / \mathrm{LaCoO}_{3} / \mathrm{SiO}_{2}$, as stated in the discussion about TPR results, over which $\mathrm{CO}$ is adsorbed on the highly dispersed platinum and would react with the oxygen species adsorbed in the perovskite vacancies [26]. The mechanism on $\mathrm{LaCoO}_{3} / \mathrm{SiO}_{2}$ is generally proposed that oxygen species, adsorbed at the oxygen vacancies on $\mathrm{LaCoO}_{3}$, react with $\mathrm{CO}$ adsorbed on $\mathrm{Co}^{3+}$ adjacent to the oxygen vacancies to generate $\mathrm{CO}_{2}$ [26]. Platinum atoms are much more active than $\mathrm{Co}^{3+}$, therefore leading to the much better activity of $\mathrm{LaCo}_{1-x} \mathrm{Pt}_{x} \mathrm{O}_{3} / \mathrm{SiO}_{2}$. For $\mathrm{Pt} / \mathrm{SiO}_{2}, \mathrm{CO}$ adsorbed on $\mathrm{Pt}$ atoms reacts with oxygen activated on the Pt surface [27], and the platinum species loaded with the regular impregnation method at a calcination temperature of $700{ }^{\circ} \mathrm{C}$ is not highly dispersed, thus showing obviously inferior activity. As for $\mathrm{LaCoPtO}_{x} / \mathrm{SiO}_{2}$, a PTO was not formed, which means that $\mathrm{Pt}$ is not in close contact with the oxide of cobalt, and the dispersion of Pt atoms would not be very high;

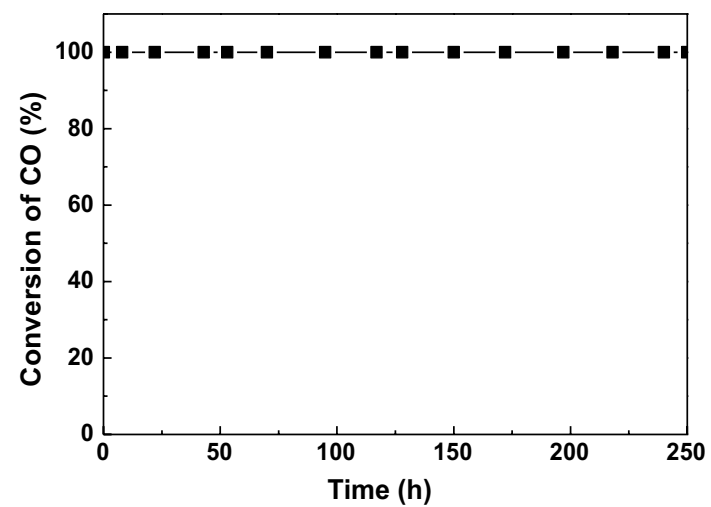

Fig. 6 Stability of $\mathrm{LaCo}_{0.95} \mathrm{Pt}_{0.05} \mathrm{O}_{3} / \mathrm{SiO}_{2}$ reduced at $220{ }^{\circ} \mathrm{C}$. Reaction conditions: $1 \% \mathrm{CO}, 1 \% \mathrm{O}_{2}, 98 \mathrm{vol} \% \mathrm{~N}_{2}$ balance at $400{ }^{\circ} \mathrm{C}$ and a space velocity of $24,000 \mathrm{~mL} /\left(\mathrm{g}_{\text {cat }} \mathrm{h}\right)$
Table 1 Some tested results of the catalysts

\begin{tabular}{lllllc}
\hline & $\begin{array}{l}\mathrm{LaCo}_{0.97} \\
\mathrm{Pt}_{0.03} \mathrm{O}_{3} / \\
\mathrm{SiO}_{2}\end{array}$ & $\begin{array}{l}\mathrm{LaCo}_{0.95} \mathrm{Pt}_{0.05} \mathrm{O}_{3} / \mathrm{SiO}_{2} \\
(\text { after stability test) }\end{array}$ & $\begin{array}{l}\mathrm{LaCo}_{0.93} \\
\mathrm{Pt}_{0.07} \mathrm{O}_{3} / \\
\mathrm{SiO}_{2}\end{array}$ & $\begin{array}{l}\mathrm{LaCo}_{0.91} \\
\mathrm{Pt}_{0.09} \mathrm{O}_{3} / \\
\mathrm{SiO}_{2}\end{array}$ & $\begin{array}{l}\mathrm{LaCo}_{0.90} \\
\mathrm{Pt}_{0.10} \mathrm{O}_{3} / \\
\mathrm{SiO}_{2}\end{array}$ \\
\hline $\begin{array}{l}\text { Amount of adsorbed CO } \\
\text { from CO-TPD ( } \mu \mathrm{mol})\end{array}$ & 1.00 & $1.58(1.53)$ & 1.96 & 2.35 & 2.48 \\
$\begin{array}{l}\text { Pt dispersion (\%) } \\
\text { CO conversion }(\%) *\end{array}$ & 92.5 & $88.3(85.1)$ & 78.2 & 74.4 & 69.1 \\
TOF $\left(\times 10^{-2} \mathrm{~s}^{-1}\right)^{*}$ & 1.35 & 1.29 & 11.69 & 13.84 & 14.42 \\
\hline
\end{tabular}

*Reaction conditions: at $145^{\circ} \mathrm{C}$; in $1 \% \mathrm{CO}, 1 \% \mathrm{O}_{2}, 98 \mathrm{vol} \% \mathrm{~N}_{2}$ balance, space velocity $=24,000 \mathrm{~mL} /\left(\mathrm{g}_{\text {cat }}\right.$ h), atmospheric pressure 
Table 2 Catalysts with good performance in recent years and compared with the catalyst in this work for $\mathrm{CO}$ oxidation at atmospheric pressure

\begin{tabular}{llcll}
\hline Catalyst $(\mathrm{wt} \%)$ & \multicolumn{2}{l}{ Stability performance } & \multirow{2}{*}{ Refs. } \\
\cline { 2 - 4 } & WHSV $(\mathrm{mL} / \mathrm{g} \mathrm{h})$ & $\mathrm{T}\left({ }^{\circ} \mathrm{C}\right)$ & Time $(\mathrm{h})$ & \\
\hline $1 \% \mathrm{Pt}-\mathrm{ZrO}_{2}$ & 30,000 & 90 & 40 & {$[28]$} \\
$5.0 \% \mathrm{Pt} / \gamma-\mathrm{Al}_{2} \mathrm{O}_{3}$ & 25,000 & 160 & 112 & {$[29]$} \\
$1 \% \mathrm{Pt} / \mathrm{Fe}_{2} \mathrm{O}_{3}$ & 96,000 & 25 & 2.2 & {$[30]$} \\
$3.32 \% \mathrm{Co} / 1.44 \% \mathrm{Pt} / \mathrm{TiO}_{2}$ & 22,000 & 45 & 2 & {$[31]$} \\
$1 \% \mathrm{Pt} / \mathrm{Ce}{ }_{0.8} \mathrm{Zr}_{0.2} \mathrm{O}_{2}$ & 16,800 & 60 & $50^{\mathrm{a}}$ & {$[32]$} \\
$\mathrm{Leached} 4 \% \mathrm{Pt}_{-0.3 \%} \mathrm{Fe} / \mathrm{CB}$ & 30,000 & 25 & 11 & {$[33]$} \\
$0.5 \% \mathrm{Pt} / \mathrm{LaCoO} / \mathrm{SiO}_{2}^{\mathrm{b}}$ & 24,000 & 400 & 250 & This work \\
\hline
\end{tabular}

${ }^{\mathrm{a}}$ The $\mathrm{CO}$ conversion is maintained at $80 \%$

${ }^{\mathrm{b}}$ The catalyst was derived from reducing $\mathrm{LaCo}_{0.95} \mathrm{Pt}_{0.05} \mathrm{O}_{3} / \mathrm{SiO}_{2}$ at $220{ }^{\circ} \mathrm{C}$ thus, $\mathrm{CO}$ oxidation proceeds via a similar mechanism to $\mathrm{LaCo}_{0.95} \mathrm{Pt}_{0.05} \mathrm{O}_{3} / \mathrm{SiO}_{2}$. Therefore, $\mathrm{LaCoPtO}_{x} / \mathrm{SiO}_{2}$ showed inferior activity compared to $\mathrm{LaCo}_{0.95} \mathrm{Pt}_{0.05} \mathrm{O}_{3} / \mathrm{SiO}_{2}$.

Figure $5 \mathrm{~b}$ shows the variations of $\mathrm{CO}$ conversion over the series of catalysts of $\mathrm{LaCo}_{1-x} \mathrm{Pt}_{x} \mathrm{O}_{3} / \mathrm{SiO}_{2}$ with the reaction temperature. The complete $\mathrm{CO}$ conversion temperatures are 280 , $240,230,215$, and $205{ }^{\circ} \mathrm{C}$ over the catalysts, when $x$ is 0.03 , $0.05,0.07,0.09$, and 0.10 , respectively, which increases with the increase in the amount of platinum present. This is in the expectation, as a higher content of platinum would provide more active sites. The TOFs, $\mathrm{CO}$ converted on per atom of platinum per second, decreased slightly with the increase in platinum content as listed in Table 1, suggesting that elevating the dispersion could improve the utilization efficiency of the noble metal platinum.

As shown in Fig. 6, $\mathrm{LaCo}_{0.95} \mathrm{Pt}_{0.05} \mathrm{O}_{3} / \mathrm{SiO}_{2}$ shows excellent stability at the high temperature of $400{ }^{\circ} \mathrm{C}$ during $240 \mathrm{~h}$ testing, as complete $\mathrm{CO}$ conversion was maintained from the start to the finish. At the same time, the dispersion of $\mathrm{Pt}$ atoms slightly decreased from 88.3 to $85.1 \%$ after the stability test, and no Pt NPs could be observed from TEM images.

It has been reported that under oxidation conditions, $\mathrm{Pt}$, $\mathrm{Pd}$, or Rh atoms on the surface of a PTO could enter into the lattice of the PTO support, thus acting as the lattice ions of the PTO. Under reduction conditions, the $\mathrm{Pt} / \mathrm{Pd} / \mathrm{Rh}$ ions in a PTO would be reduced to metal atoms and migrate out onto the surface of the PTO. The "entering into" and "migrating out" may cycle under certain atmospheres, meaning that Pt/ $\mathrm{Pd} / \mathrm{Rh}$ species may be cycling between the surface and lattice of a PTO [13, 14, 34, 35]. This cycling might function for $\mathrm{LaCo}_{0.95} \mathrm{Pt}_{0.05} \mathrm{O}_{3} / \mathrm{SiO}_{2}$ in the $\mathrm{CO}$ oxidation reaction process, considering that the reaction gas mixture contains $\mathrm{CO} /$ $\mathrm{O}_{2}$ at a ratio of 1:1. Therefore, the highly dispersed platinum atoms showed excellent sintering resistance ability. At least, the Pt species could interact with the support of $\mathrm{LaCoO}_{3}$, and the interaction would prevent the Pt atoms from moving, therefore showing excellent sintering resistance ability.

Table 2 summarizes representative excellent Pt-based catalysts developed in recent years and compares them with the $\mathrm{LaCo}_{0.95} \mathrm{Pt}_{0.05} \mathrm{O}_{3} / \mathrm{SiO}_{2}$ of this work. It can be seen that
$\mathrm{LaCo}_{0.95} \mathrm{Pt}_{0.05} \mathrm{O}_{3} / \mathrm{SiO}_{2}$ exhibited excellent stability, which was tested at an obviously higher temperature and maintained for a much longer time compared to other reactions in the table.

To combine the above results, the process shown in Scheme 1 is analyzed as follows. A PTO of $\mathrm{LaCo}_{1-x} \mathrm{Pt}_{x} \mathrm{O}_{3}$ was highly dispersed on $\mathrm{SiO}_{2}$ with a high surface area, and the platinum ions should be uniformly dispersed in the PTO lattice. In the reduction process, platinum ions should be reduced and migrate out from the lattice onto the surface of $\mathrm{LaCoO}_{3}$. In the lattice of $\mathrm{LaCo}_{1-x} \mathrm{Pt}_{x} \mathrm{O}_{3}$, platinum ions were uniformly dispersed; therefore, in the reduction process, platinum ions should migrate out evenly and highly disperse on the surface of $\mathrm{LaCoO}_{3}$. When the content of platinum in $\mathrm{LaCo}_{1-x} \mathrm{Pt}_{x} \mathrm{O}_{3}$ is low, the platinum atoms (migrated from the lattice of $\mathrm{LaCo}_{1-x} \mathrm{Pt}_{x} \mathrm{O}_{3}$ ) would be highly dispersed. When $x$ in $\mathrm{LaCo}_{0.95} \mathrm{Pt}_{0.05} \mathrm{O}_{3} / \mathrm{SiO}_{2}$ is 0.05 or below, the characterization results suggest that the content of platinum is low enough, as when $x=0.03$ and 0.05 , the dispersions of $\mathrm{Pt}$ are 92.5 and $88.3 \%$, respectively, and no Pt NPs could be found by using high-resolution TEM. It is accepted that $\mathrm{Pt}$ atoms can activate $\mathrm{CO}$ and the oxygen vacancies can activate oxygen, and the two activated species therefore bond to generate $\mathrm{CO}_{2}$, leading to the high activity for $\mathrm{CO}$ oxidation.

\section{Conclusions}

Highly dispersed Pt catalysts can be prepared by using PTOs as the precursor via a simple method of citrate acid complexation combined with impregnation. Specifically, in $\mathrm{LaCo}_{0.95} \mathrm{Pt}_{0.05} \mathrm{O}_{3} / \mathrm{SiO}_{2}$, the PTO of $\mathrm{LaCo}_{0.95} \mathrm{Pt}_{0.05} \mathrm{O}_{3}$ could be highly dispersed on $\mathrm{SiO}_{2}$ supports, and after reduction, $\mathrm{Pt} /$ $\mathrm{LaCoO}_{3} / \mathrm{SiO}_{2}$ was generated, where the platinum was highly dispersed, since the platinum ions were uniformly dispersed in the precursor of $\mathrm{LaCo}_{0.95} \mathrm{Pt}_{0.05} \mathrm{O}_{3}$. It is interesting to note that the highly dispersed Pt exhibited excellent resistance to sintering, being attributed to the confinement of $\mathrm{Pt}$ atoms by $\mathrm{LaCoO}_{3}$ on $\mathrm{SiO}_{2}$. Thus, the prepared catalyst showed high activity and excellent stability for $\mathrm{CO}$ oxidation. 
Acknowledgements This work was supported by the National Natural Science Foundation of China (Nos. 21576192, 21776214).

Open Access This article is distributed under the terms of the Creative Commons Attribution 4.0 International License (http://creativeco mmons.org/licenses/by/4.0/), which permits unrestricted use, distribution, and reproduction in any medium, provided you give appropriate credit to the original author(s) and the source, provide a link to the Creative Commons license, and indicate if changes were made.

\section{References}

1. Thomas JM, Saghi Z, Gai PL (2011) Can a single atom serve as the active site in some heterogeneous catalysts? Top Catal 54(10-12):588-594

2. Ranocchiari M, Lothschütz C, Grolimund D et al (2012) Singleatom active sites on metal-organic frameworks. Proc R Soc A Math Phys Eng Sci 468:1985-1999

3. Job N, Pereira MFR, Lambert S et al (2006) Highly dispersed platinum catalysts prepared by impregnation of texture-tailored carbon xerogels. J Catal 240(2):160-171

4. Zhai Y, Pierre D, Si R et al (2010) Alkali-stabilized Pt-OHx species catalyze low-temperature water-gas shift reactions. Science 329:1633-1636

5. Yang M, Li S, Wang Y et al (2014) Catalytically active Au$\mathrm{O}(\mathrm{OH})_{x}$-species stabilized by alkali ions on zeolites and mesoporous oxides. Science 346(6216):1498-1501

6. Uzun A, Ortalan V, Browning ND et al (2010) A site-isolated mononuclear iridium complex catalyst supported on $\mathrm{MgO}$ : characterization by spectroscopy and aberration-corrected scanning transmission electron microscopy. J Catal 269(2):318-328

7. Ramos-Fernandez EV, Pieters C, Van der Linden B et al (2012) Highly dispersed platinum in metal organic framework $\mathrm{NH}_{2}$-MIL-101(Al) containing phosphotungstic acid-characterization and catalytic performance. J Catal 289:42-52

8. Watanabe M, Uchida M, Motoo S (1987) Preparation of highly dispersed $\mathrm{Pt}+\mathrm{Ru}$ alloy clusters and the activity for the electrooxidation of methanol. J Electroanal Chem Interfacial Electrochem 229(1-2):395-406

9. Qiao B, Wang A, Yang X et al (2011) Single-atom catalysis of CO oxidation using $\mathrm{Pt}_{1} / \mathrm{FeO}_{x}$. Nat Chem 3:634-641

10. Liu P, Zhao Y, Qin R et al (2016) Photochemical route for synthesizing atomically dispersed palladium catalysts. Science 352(6287):797-801

11. Jones J, Xiong H, Delariva AT et al (2016) Thermally stable single-atom platinum-on-ceria catalysts via atom trapping. Science 353(6295):150-154

12. Katz MB, Zhang S, Duan Y et al (2012) Reversible precipitation/ dissolution of precious-metal clusters in perovskite-based catalyst materials: bulk versus surface re-dispersion. J Catal 293:145-148

13. Jarrige I, Ishii K, Matsumura D et al (2015) Toward optimizing the performance of self-regenerating Pt-based perovskite catalysts. ACS Catal 5(2):1112-1118

14. Taniguchi M, Tanaka H, Uenishi M et al (2007) The selfregenerative Pd-, Rh-, and Pt-perovskite catalysts. Top Catal 42(1-4):367-371

15. Kingsley JJ, Pederson LR (1993) Combustion synthesis of perovskite $\mathrm{LnCrO}_{3}$ powders using ammonium dichromate. Mater Lett 18(1-2):89-96

16. Tanksale A, Beltramini JN, Dumesic JA et al (2008) Effect of Pt and Pd promoter on Ni supported catalysts - a TPR/TPO/TPD and microcalorimetry study. J Catal 258(2):366-377
17. Lanyon MAH, Trapnell BMW (1955) The interaction of oxygen with clean metal surfaces. Proc R Soc Lond Ser A Math Phys Sci 227(1170):387-399

18. Jia AP, Jiang SY, Lu JQ et al (2010) Study of catalytic activity at the $\mathrm{CuO}-\mathrm{CeO}_{2}$ interface for $\mathrm{CO}$ oxidation. J Phys Chem $\mathrm{C}$ 114(49):21605-21610

19. Niu T, Liu GL, Liu Y (2014) Preparation of Ru/graphene-mesomacroporous $\mathrm{SiO}_{2}$ composite and their application to the preferential oxidation of $\mathrm{CO}$ in $\mathrm{H}_{2}$-rich gases. Appl Catal B Environ 154-155:82-92

20. Tang H, Li S, Gong D et al (2017) Bimetallic Ni-Fe catalysts derived from layered double hydroxides for $\mathrm{CO}$ methanation from syngas. Front Chem Sci Eng 11(4):613-623

21. Levasseur B, Kaliaguine $\mathrm{S}$ (2008) Methanol oxidation on $\mathrm{LaBO}_{3}$ $(\mathrm{B}=\mathrm{Co}, \mathrm{Mn}, \mathrm{Fe})$ perovskite-type catalysts prepared by reactive grinding. Appl Catal A Gen 343(1-2):29-38

22. Sun S, Yang L, Pang G et al (2011) Surface properties of Mg doped $\mathrm{LaCoO}_{3}$ particles with large surface areas and their enhanced catalytic activity for CO oxidation. Appl Catal A Gen 401(1-2):199-203

23. Kozlova EA, Korobkina TP, Vorontsov AV et al (2009) Enhancement of the $\mathrm{O}_{2}$ or $\mathrm{H}_{2}$ photoproduction rate in a $\mathrm{Ce}^{3+} / \mathrm{Ce}^{4+}-\mathrm{TiO}_{2}$ system by the $\mathrm{TiO}_{2}$ surface and structure modification. Appl Catal A Gen 367(1-2):130-137

24. Jermwongratanachai T, Jacobs G, Wenping $M$ et al (2013) Fischer-Tropsch synthesis: comparisons between Pt and Ag promoted $\mathrm{Co} / \mathrm{A} 12 \mathrm{O} 3$ catalysts for reducibility, local atomic structure, catalytic activity, and oxidation-reduction (OR) cycles. Appl Catal A Gen 464-465:165-180

25. Birgersson H, Eriksson L, Boutonnet $M$ et al (2004) Thermal gas treatment to regenerate spent automotive three-way exhaust gas catalysts (TWC). Appl Catal B Environ 54(3):193-200

26. Viswanathan B (1992) CO oxidation and NO reduction on perovskite oxides. Catal Rev 34(4):337-354

27. Eiswirth M, Möller P, Wetzl K et al (1989) Mechanisms of spatial self- organization in isothermal kinetic oscillations during the catalytic CO oxidation on Pt single crystal surfaces. J Chem Phys 90(1):510-521

28. Singhania A, Gupta SM (2017) Nanocrystalline $\mathrm{ZrO}(2)$ and $\mathrm{Pt}-$ doped $\mathrm{ZrO}(2)$ catalysts for low-temperature $\mathrm{CO}$ oxidation. Beilstein J Nanotechnol 8:264-271

29. Avgouropoulos G, Ioannides T, Papadopoulou Ch et al (2002) A comparative study of $\mathrm{Pt} / \gamma-\mathrm{Al}_{2} \mathrm{O}_{3}, \mathrm{Au} / \alpha-\mathrm{Fe}_{2} \mathrm{O}_{3}$ and $\mathrm{CuO}-\mathrm{CeO}_{2}$ catalysts for the selective oxidation of carbon monoxide in excess hydrogen. Catal Today 75:157-167

30. Li S, Liu G, Lian H et al (2008) Low-temperature CO oxidation over supported Pt catalysts prepared by colloid-deposition method. Catal Commun 9(6):1045-1049

31. Epling WS, Cheekatamarla PK, Lane AM (2003) Reaction and surface characterization studies of titania-supported $\mathrm{Co}, \mathrm{Pt}$ and $\mathrm{Co} / \mathrm{Pt}$ catalysts for the selective oxidation of $\mathrm{CO}$ in $\mathrm{H} 2$-containing streams. Chem Eng J 93(1):61-68

32. Roh HS, Potdar HS, Jun KW et al (2004) Low temperature selective $\mathrm{CO}$ oxidation in excess of $\mathrm{H}_{2}$ over $\mathrm{Pt} / \mathrm{Ce}-\mathrm{ZrO}_{2}$ catalysts. Catal Lett 93(3-4):203-207

33. Xu H, Fu Q, Yao Y et al (2012) Highly active Pt-Fe bicomponent catalysts for $\mathrm{CO}$ oxidation in the presence and absence of $\mathrm{H}_{2}$. Energy Environ Sci 5:6313-6320

34. Tanaka H, Taniguchi M, Uenishi M et al (2006) Self-regenerating $\mathrm{Rh}$ - and Pt-based perovskite catalysts for automotive-emissions control. Angew Chem Int Edn 45(36):5998-6002

35. Tanaka H, Uenishi M, Taniguchi M et al (2006) The intelligent catalyst having the self-regenerative function of $\mathrm{Pd}, \mathrm{Rh}$ and $\mathrm{Pt}$ for automotive emissions control. Catal Today 117(1-3):321-328 